\title{
The Roots of Racialized Travel Behavior
}

Jesus M. Barajas

March 17, 2021

\begin{abstract}
Transportation inequities, particularly in the United States, result in part from historical and contemporary racism in planning, policy, urban development, decision making, and societal institutions. They have limited the mobility and access to opportunity for Black, Indigenous, and people of color, and shaped the ways that they travel. This chapter reviews the literature on racial and ethnic identity in travel behavior, examining the history and claims of transportation injustice. The chapter explores the barriers that historically marginalized communities experience as a result of disproportionate policing, safety and security issues, and neighborhood othering and belonging - that is, inviting suspicion because a person appears to be "out of place" in a neighborhood. It concludes by making the case for why transportation planners must consider race and racism explanatory factors in travel and why race-neutral planning processes exacerbate disparities.
\end{abstract}

Keywords: travel behavior, race, policing, safety, transportation planning, mobility justice

\section{Introduction}

Between 1936 and 1966, Victor Hugo Green published an annual travel guide called The Negro Motorist Green Book. The book listed hotel accommodations, restaurants, and other travel services that would cater to Black Americans during a time of legal segregation as they road-tripped across the United States. Post-World War II prosperity lead to the rapid rise of automobile ownership across the United States and with it, a sense of freedom to travel recreationally and set sights to distant destinations. But the existence of the Green Book serves as a reminder that as the automobile took hold of the landscape, policy, and cultural image of the country, Black Americans were routinely denied access to the full benefits of the car (Sorin 2021). "African Americans' desire and fitness for citizenship were tethered to and divined in their participation in automobility," Cotton Seiler (2006, 1092) wrote, and Jim Crow laws in the South-laws that enforced racial segregation - and racial prejudice everywhere made it impossible for them to achieve that full citizenship. Private businesses of all types restricted mobility through "whites only" services, preventing Black people from being in spaces not designated for them, while the government did the same through racially-motivated policing and violence. Similar dynamics were in play for other marginalized groups as well; for example, Carpio (2019) has argued that mobility of all forms, from the automobile to the larger forces of migration and new urban developments, shaped racial hierarchies during the 20th century among Japanese, Mexican, and other immigrant groups in southern California - a region nearly defined by its obsession with the automobile and

This is a pre-print of a published book chapter. Please cite as follows:

Barajas, Jesus M. 2021. “The Roots of Racialized Travel Behavior.” In Social Issues in Transportation (Advances in Transport Planning and Policy Vol. 8), edited by Rafael H. M. Pereira and Geneviève Boisjoly. Elsevier.

https://doi.org/10.1016/bs.atpp.2021.06.007 
perpetual motion. Racial identities, ${ }^{1}$ because they have often been the basis by which mobility was restricted, have influenced travel experiences.

The Green Book and similar guidebooks responded to the needs caused by individualized, but widespread, racial animus. But systematic racism in government decision making also limited the mobility of Black people and other people of color on a scale much broader than vacation travel. A long list of deliberate actions transpired to make this the case from the dawn of the highway era to today: residential segregation that prevented people of color from moving to suburbs characterized by nearly unlimited automobility; the purposeful construction of highways through Black neighborhoods as a means of urban renewal; and transit funding formulas that have favored rail construction, disfavored bus operating expenses, and offered higher subsidies for commuter rail that overwhelming serve white passengers, just to name a few examples (Bullard 2004; Rothstein 2017; Garrett and Taylor 1999). These planning and engineering processes have led to distributive injustices-people of color have received fewer benefits and shouldered higher burdens from transportation investment - as well as procedural injustices, because people of color have had little voice and representation when these decisions have been made. Since the 1960s, civil rights and environmental justice legislation have forced transportation agencies to acknowledge and identify racial disparities in an attempt to prevent such injustices from continuing to happen, but scholars have argued that the mere identification of inequities and mitigation of disproportionate impact do little to remedy the consequences of historical decisions that caused the disparities in the first place (Martens 2017; Sheller 2018; Karner et al. 2020).

This historical context helps explain how race and identity shape travel behavior today. In this chapter, I detail the roots of racialized travel behavior in the United States and make the case for why transportation planners must consider race and racism as explanatory factors in travel and why race-neutral planning processes exacerbate disparities. I then share additional historical background of how race and racism have been embedded in historical transportation decision making processes. I next describe three issues in which racial identity is especially salient: policing and the law, safety and security, and the ideas of belonging and othering. Finally, I conclude with implications for changes in transportation practice and policy. Together, these issues comprise what planner and researcher Charles Brown (2021) has termed "arrested mobility" and call on the transportation community to both understand and remedy injustice.

\section{The limitations of race-neutral travel behavior analysis}

Travel behavior can be thought as a set of realized practices in response to the availability of transportation resources and a supportive context for enabling travel. The determinants of travel

\footnotetext{
${ }^{1}$ I use the terms "race" and "racial identities" synonymously with "ethnicity" in this chapter. While Hispanic or Latino identity is an ethnicity rather than a race, for example, Latinos in the United States have been racialized as Brown regardless of culture or country of origin (García 2020).
} 
behavior are complex; the assumption most widely used in travel demand forecasting is that travelers make choices consistent with economic rationality, perhaps subject to some heterogeneity in preferences across the population (Ben-Akiva and Lerman 1985; Meyer and Miller 2001). People will choose transportation modes, travel routes, and destinations according to the options that will cost them the least amount or time or money. Those decisions are bound by the resources they have; a person cannot drive, for example, if they do not have access to a vehicle. But economic rationality is not the only or the best way to characterize travel behavior. Scholars from traditions in psychology and public health have shown that other attributes and domains affect decisions: attitudes, subjective norms, perceptions of the ability to carry out a behavior, sociocultural relationships, individual characteristics, and the built and natural environments feature in various theoretical models of travel behavior (Ajzen 1991; Sallis et al. 2006; Handy and Xing 2011; Schneider 2013). Racial identity figures into these domains because many past decisions were discriminatory on the basis of race, but race is rarely acknowledged as a causal factor in travel behavior.

Traditional planning methods are not equipped to analyze transportation through a racialized framework because race is undertheorized in explanatory analyses or deliberately omitted from quantitative transportation models. Racial categories are used as descriptive variables when identifying impacts, such as by measuring whether a new transit line will provide access to a majority Latino neighborhood or whether a certain share of Black drivers will experience travel time savings from a freeway expansion. But these analyses do not measure why, for example, access to transit may not induce Latino residents in the neighborhood to use the system or why Black drivers may not want the freeway expansion in the first place. Travel demand models used to develop long range transportation plans exclude race as an explanatory-or even controlfactor because analysts have argued that while we observe differences in travel patterns by race, race does not cause those differences and so its inclusion as a variable in explaining behavior is inappropriate (Karner and Niemeier 2013). These omissions, deliberate or not, are often reflections of the disciplinary and personal backgrounds and priorities of transportation professionals (Vigar 2017; Lowe 2020).

Nevertheless, racial identity does matter when explaining travel behavior because of the way race operates as a social construct, particularly, but not exclusively, in the United States. It is true that one does not find themselves unable to afford a car because of phenotype; income is the direct determinant. But a Black shopper might be denied credit or quoted a higher price because an auto dealer discriminates, making race an indirect causal factor (Ayres and Siegelman 1995; Rice and Schwartz, Jr. 2018). Likewise, inability to walk or bike places may be impossible because of a lack of connectivity due to physical barriers such as highway infrastructure. Again, that does not happen because one has dark skin, but because decision-makers disproportionately placed freeway infrastructure in communities of color (Adkins et al. 2017). And the criminalization of Black and brown bodies places even further barriers on mobility from outside the transportation domain (Seo 2019). An updated model of travel behavior would explicitly center racial identity and racism as 
explanatory factors because of the ways they intersect with other individual characteristics, the social environment, the built environment, and the regulatory frameworks in which those domains are embedded (Figure 1). This conceptual model proposes that individual factors, such socioeconomic characteristics and travel constraints, attitudes and perceptions toward transportation and land use characteristics, social networks, and urban form together with the physical environment are interrelated and influence one another (Handy and Xing 2011; Barajas 2016). Those factors influence the ways people move around. But the web of relationships is affected by wide-ranging policies and regulations, which in turn have been shaped by the ways that racism have pervaded public decision making. For these reasons, race-neutral transportation planning risks reinforcing, rather than resolving, systemic injustices.

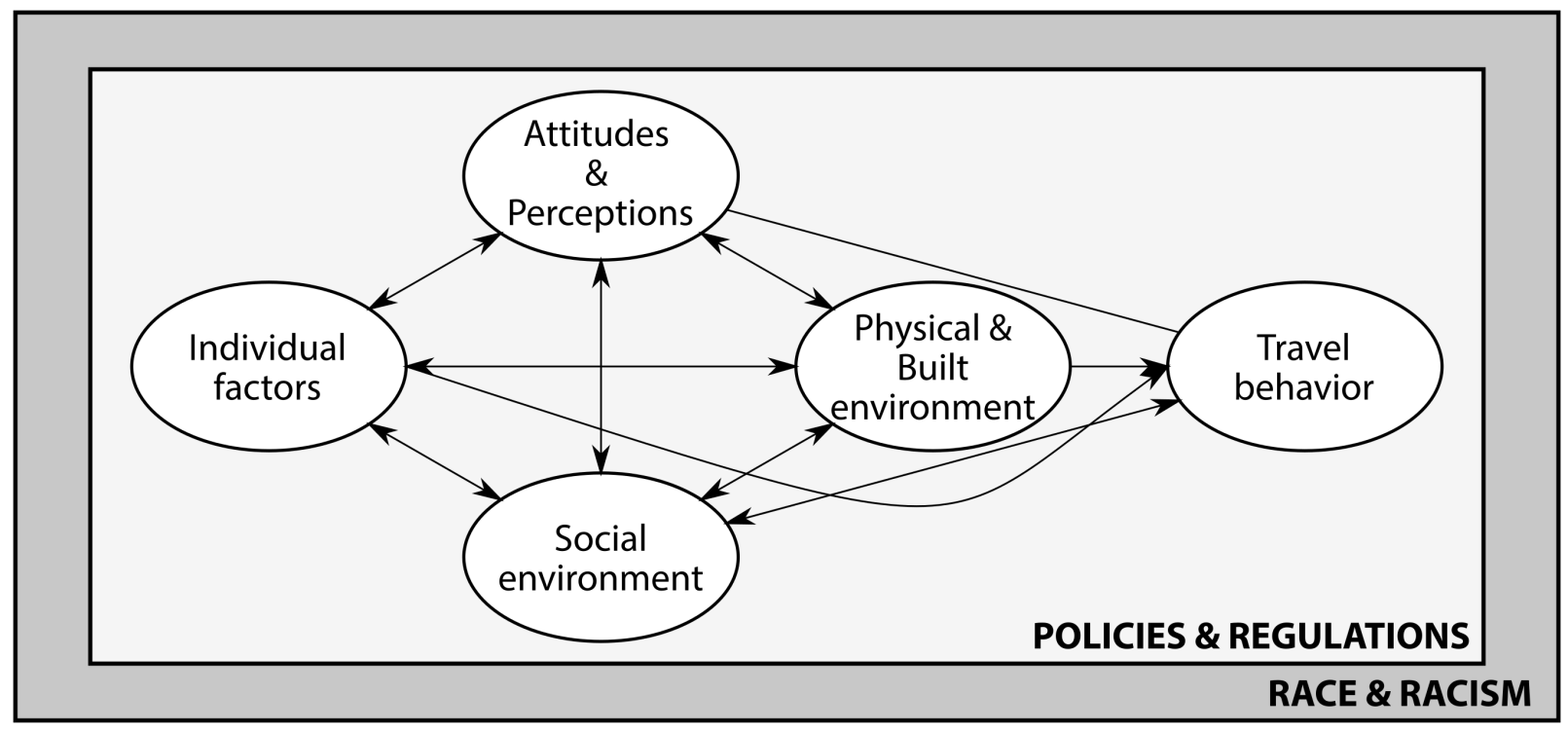

Figure 1: A proposed conceptual framework of travel behavior, centering race and racism as explanatory factors for travel behavior. Adapted from Handy and Xing (2011) and Barajas (2016).

\section{Mobility and its limits from yesterday to today}

Transportation is just one manifestation of mobility, which can be characterized not only by dayto-day travel but also by migration and the flows of ideas. Freedom and mobility have been twin ideals in the United States from its colonial roots. Settling on the shores of a "new" world by moving from the old brought freedoms eventually codified in the constitution of the new country. After independence, settlers marched continually westward across the continent, establishing trading towns, forming organized territories, and eventually joining the union as an integral part of the US. But this perpetual mobility has always come at the expense of people who are Indigenous, Black, or people of color. Colonial encroachment on Native lands led to death and displacement as white settlers warred with and forcibly removed entire peoples from their ancestral homes (Dunbar-Ortiz 2014). The links between freedom and mobility were especially clear in the 
antebellum South; enslaved Africans could go only where slaveholders said they could go. Should they have chosen to go beyond those limits, enslaved people were returned and punished for deigning to be mobile. The Fugitive Slave Act of 1850 saw to it that agents of the federal government were to act as the police of "fugitives from service or labor" no matter where in the jurisdiction of the United States they escaped to (Campbell 1970).

The conclusion of the US Civil War brought the end of slavery but not the end of restrictions on Black mobility. While Black men were accorded the same rights and privileges as white men under the law, entrenched white power in the South prohibited them from exercising those rights in fact. Real property promised by the federal government to African Americans after emancipation was never delivered, and a system of sharecropping in which renters paid for their homes by returning a portion of their crop to the landowner chained most Black farmers to the land and curtailed economic mobility (Royce 1993). For those with means to survive outside of this form of economic slavery, Black mobility was restricted at different scales, especially after the end of the Reconstruction era in the late 1870s. Under Jim Crow laws, public and private spaces became segregated, wherein the movement of Black people was policed at a micro-scale. Some of the first segregated spaces were rail cars. It was in defiance of this segregation that Plessy v. Ferguson was brought before the Supreme Court in 1896, after Homer Plessy, an African American man, refused to move from a whites-only train car in Louisiana and was arrested. The Court held that separate facilities were constitutional so long as they were equal, entrenching the restrictions on Black movement with the force of law (Woodward 1964).

Between the late 1800s and the 1960s, transportation continued to be at the heart of the struggles for freedom and mobility under the specter of institutional racism and state policing power. Indeed, one of the initial sparks of the Civil Rights Movement was the Montgomery Bus Boycott, a protest against the treatment of Black people as second-class citizens on public transportation (Bullard 2004). Even after laws enforcing racial segregation on transportation were struck down by the Supreme Court, southern states refused to acknowledge them and continued to enforce the invalidated discriminatory statutes. This prompted the Freedom Rides in 1961, where racially integrated teams rode interstate buses in the South to bring attention to continued segregation (Arsenault 2006). Eventually, the Freedom Riders prevailed and the Interstate Commerce Commission, which regulated buses and trains that cross state lines, began to enforce its antisegregation policies.

\section{The reconfiguring of communities of color and justice responses}

\section{The racism of transportation infrastructure development}

Although the Freedom Rides and other Civil Rights actions helped end segregation on public and private carriers, discrimination and racial policing in transportation persists today. The automobile is now the vehicle by which many people experience today's issues of transportation inequity, from policing to safety. The car has become the quintessential symbol of freedom across the globe; 
car ownership grew by an average of $4.6 \%$ year-over-year in the second half of the 20th Century, and by an even greater 7.5\% in developing countries (Dargay, Gately, and Sommer 2007). Empirical evidence in transportation psychology have shown strong and reinforcing links between positive affect, such as pride, status, and independence, and car use (Steg, Geurs, and Ras 2001; Moody and Zhao 2020). Some scholars have argued that we are now living in a "system of automobility," in which "automobility has reshaped citizenship and the public sphere via the mobilization of civil societies" (Sheller and Urry 2000, 739). As I will argue later, biased policing of this automobility constrains drivers of color to being less than full participants in society.

It is hard to understate the inequities for people of color caused by the automobile and auto-centric development in the United States. The stage was set through housing and land use policies that fostered racial segregation in the early part of the 20th century, followed by the use of transportation infrastructure as a means for urban renewal (Rothstein 2017). The suburbs could not have been built - and the white flight to them could not have occurred - without the benefit of transportation infrastructure. New suburban homes were generally built along electric streetcar or trolley lines, run by private corporations and sometimes subsidized by housing developers themselves to ensure access to their developments (Jackson 1985). In many places, however, homes would not be sold to African Americans either because zoning codes explicitly forbade it at the municipal level or because racially-restrictive covenants on housing deeds prevented it at the individual level (Rothstein 2017). Both means of discrimination in the housing market were invalided by the US Supreme Court in separate cases, though local governments, developers, and real estate agents continued to find indirect ways to segregate.

The federal government was also complicit in the project of racial segregation. As more homes were being built but as economic conditions worsened in the Great Depression, the United States established two new housing programs to spur home ownership: the Home Owners Loan Corporation (HOLC), which issued its own loans, and the Federal Housing Administration (FHA), which insured bank-issued mortgages. Because the federal government was on the hook in case of default, they needed a way to ensure that the properties backed by the loans were of sufficient quality to maintain their values (Rothstein 2017). The appraisals were based primarily on the characteristics of the neighborhoods, color-coded on maps from the "best" neighborhoods (green) to "hazardous" neighborhoods (red), and guarantees would not be applied for loans to borrowers in the red neighborhoods ("redlining"). The assessment of neighborhood quality was almost invariably judged by the preponderance of the racial groups that lived there, using terms such as "infiltration" and "undesirable" to describe African Americans, Asians, and other people of color and immigrant groups as akin to forms of environmental pollution (Nelson et al. n.d.). In this way, official programs severely limited the opportunities of Black residents and other people of color to own and improve homes, depressing their values through redlining. 


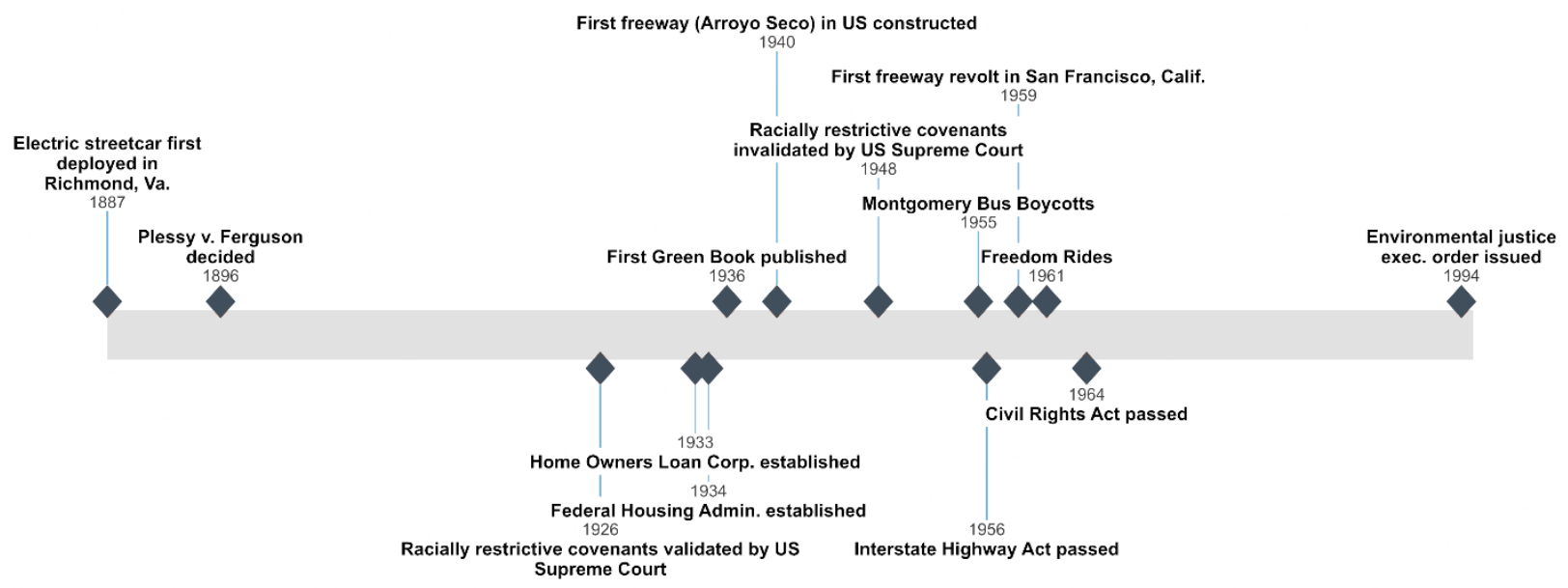

Figure 2: Selected events relevant to racialized experiences in transportation

The low economic value of land only compounded racially-motivated decisions to site new freeway infrastructure in predominately Black neighborhoods and neighborhoods of color. While highway construction began not long after the public began purchasing autos en masse, roadbuilding got a boost after the passage of the Federal-Aid Highway Act of 1956. The law ushered in the Interstate Highway era by pledging to pay 90 cents on the dollar for every project built. In many cases, that infrastructure was deliberately designed to traverse Black neighborhoods, both before and after the Act, in the name of slum clearance and urban renewal (Bullard 2004; Rothstein 2017). The new auto-oriented infrastructure displaced Black residents and other people of color groups for the benefit of commuters who came into the city by day and left for the suburbs at night. Freeways built in St. Paul, Minn., Miami, New Orleans, Los Angeles, and elsewhere destroyed the fabric of tight-knit Black and Latino communities or otherwise redefined the landscape of the residents who remained (Avila 2014). The legacy of New York City commissioner Robert Moses, who above all shaped the city as we know it today, has been well documented for its racist effects there, bulldozing through low-income neighborhoods and deliberately building parkway overpasses low enough that public transit vehicles could not take city residents to beaches and outlying parks as just two examples (Caro 1975; Lewis 2013). The commissioner was able to get legislation passed to prohibit buses and commercial vehicles from using state parkwaysoriginally designed to be linear parks with to recreational destinations on Long Island, but quickly turned into commuter routes. He coupled law with the permanence of construction to ensure that buses that served mostly Black city residents would never be able to use those parkways; none of the 204 bridges spanning the parkways exceeded 13 feet in height, the standard size of a city bus (Caro 1975). Some have argued that the bridge heights were consistent with earlier parkway designs, but the average height of the first bridges built under Moses were significantly lower than previous examples (Campanella 2017).

While limited-access highways were the main culprit in the displacement of Black residents and other people of color via transportation, rail infrastructure developed for the benefit of suburb-to- 
city commuters harmed communities in some instances as well. The San Francisco Bay Area Rapid Transit (BART) system was oriented around getting office workers from the farther reaches of the region into San Francisco. And while the rail system ran above ground down the heart of West Oakland's Black business district, it was undergrounded in wealthier parts of the urban core like San Francisco and North Berkeley (Golub, Marcantonio, and Sanchez 2013). Few modern-day projects are as explicitly destructive to residential and commercial infrastructure, but the fabric of communities of color has been disrupted by the gentrification and displacement processes associated with transit and bicycle investment (Zuk et al. 2018; Padeiro, Louro, and Costa 2019; Lubitow and Miller 2013; Flanagan, Lachapelle, and El-Geneidy 2016).

\section{Justice frameworks in transportation}

The deliberate destruction of Black, Indigenous, and People of Color communities via transportation infrastructure no longer happens on the scale that it once did. Multiracial coalitions formed to lead freeway revolts beginning in the late 1950s and, in a series of hard-fought wins, led to the cancellation or rerouting of infrastructure and some recognition of the harms that construction caused (Mohl 2004; Avila 2014). These and other struggles for transportation justice can be thought of as precursors to the environmental justice movement. The movement was born when residents of majority Black Warren County, North Carolina, one of the poorest counties in the state, protested construction of a landfill meant to contain toxic waste that had been illegally dumped along rural highway shoulders (McGurty 2000). Much like in the fight for civil rights two decades earlier, transportation was central to contested claims about the unfair distribution of goods and harms toward people of color and the recognition of people to make those claims (Schlosberg 2009).

Together with traditional community organizing, frameworks of environmental justice, environmental racism, and transportation racism have been used by advocates in their struggles for fair transportation systems. In part, this is helped by federal law and policies: Title VI of the Civil Rights Act and the Environmental Justice executive order together prohibit discrimination of the receipt of federal funds on the basis of race and direct federal agencies to ensure no group protected by the laws receives disproportionate benefits or experiences disproportionate burdens. Transportation advocates have used evidence of racial disparities and organized campaigns to achieve goals such as lower transit fares and more parity in funding for bus and rail modes (Mann 2004; Grengs 2005), elimination of diesel buses from Black neighborhoods (Bullard, Johnson, and Torres 2004), defeating the long-blocked expansion of transit service into a majority Black, highpoverty county (Karner and Duckworth 2019), and greater investment in cycling programs and infrastructure in Latino communities (Lubitow, Zinschlag, and Rochester 2016; Moore-Monroy et al. 2016). Although these wins are worthy of celebration, they reflect only incremental and sitespecific improvements in equitable transportation. They do not begin to achieve deep structural change and belie the near futility that justice advocates have faced when seeking government remedy because of the state's entrenched interests in maintaining the status quo (Pulido 2017; Karner et al. 2020). 
The imprint of the historical processes reviewed earlier remain to limit mobility and opportunity for people of color, despite the small wins to achieve a fairer distribution of resources and the policies that purport to protect that fair distribution. These practices and systems have yielded a long list of distributional inequities in the benefits and burdens of transportation as well as in the processes of transportation planning: people of color have lower access to vehicles and transportation service, jobs and opportunities, active transportation infrastructure, and new mobility services, and suffer from poorer health outcomes related to emissions and inactive travel (Ihlanfeldt and Sjoquist 1998; Grengs 2012; Rowangould 2013; Mueller et al. 2015; Karner, Rowangould, and London 2016; R. J. Lee, Sener, and Jones 2017; Braun, Rodriguez, and GordonLarsen 2019; Bastiaanssen, Johnson, and Lucas 2020). Environmental justice policy and civil rights legislation that seek to ensure racial equity in transportation access look to the future but do not assure "restorative justice" or reparations for past harms, which several scholars have argued is a logical goal emanating from Civil Rights legislation (Marcantonio et al. 2017; Martens and Golub 2018). Multiple barriers exist to this sort of affirmative action: geographic equity considerations often mean that urban areas - the locations of most historical damage from transportation planning - receive less than a fair share of transportation funding; the composition of regional transportation boards often does not reflect the diversity among their constituents; and racial equity criteria are sparingly used when prioritizing transportation projects (Sciara and Wachs 2007; Sanchez and Wolf 2007; Manaugh, Badami, and El-Geneidy 2015; Martens and Golub 2018; Krapp, Barajas, and Wennink 2021). Some scholars have proposed that a way forward for transportation justice in planning practice is to shift the object of equity from the distribution of mobility or resources to the distribution of accessibility (Pereira, Schwanen, and Banister 2017; Martens 2017; Levine, Grengs, and Merlin 2019). By seeking to raise average access across groups while also minimizing access disparities, those who have been left behind by previous planning practices will see their fortunes rise to a greater degree (Martens, Golub, and Robinson 2012; Pereira, Schwanen, and Bannister 2017).

Other scholars have argued that achieving justice requires a shift in focus from measuring and comparing transportation outcomes to addressing a variety of other injustices that people of color face when it comes to free movement. Sheller (2018) has proposed mobility justice as a critical theoretical framework that builds upon environmental justice, spatial justice, and transportation justice and which considers movement as the fundamental object of justice. Because we are creatures who spend our lives on the move, Sheller argues, understanding disparities in access to transportation is not enough to achieve justice: "Beyond access to transport, we need to understand the ways in which uneven mobilities produce differentially enabled (or disabled) subjects and differentially enabling (or disabling) spaces" (Sheller 2018,28). While distributive justice has been the main means by which transportation theorists and practitioners have conceived of fairness in the transportation system (e.g. Pereira, Schwanen, and Banister 2017; Martens 2017; Pereira and Karner 2021), a mobility justice perspective points out distribution is just one of many inequities that people of color face. Recognition of groups and expertise, access to power and decision making, and the valuation of knowledge are all facets of planning in which people of color have 
been denied full participation (Sheller 2018). A transportation system based on mobility justice thus calls on practitioners and advocates to center race and identity in their processes, acknowledge and seek to repair harm, look beyond modes of transportation to people and their needs, and value community experiences as essential data for decision making (Untokening Collective 2017). Mobility justice perspectives also highlight hidden connections to transportation, such as educational equity (Bierbaum, Karner, and Barajas 2020) and gendered and intersectional violence in transportation systems (Lubitow, Abelson, and Carpenter 2020; Loukaitou-Sideris et al. 2020; Ding, Loukaitou-Sideris, and Agrawal 2020).

\section{Understanding the intersections of race, racism, and travel behavior}

The history of racist practices, both individual and systemic, has affected the way that people of color lived and moved about. Land use and transportation systems segregated people and inflicted significant damage to neighborhoods, and methods and theories that planners have used have shown to be inadequate in providing remedy for these actions. While the questions of which groups benefit from and are burdened by transportation fall under the purview of transportation professionals, many issues that influence how people travel are not explicitly transportationrelated. And yet these issues speak to how race is central to travel. This section will address three of these issues: policing and the law, safety and security, and neighborhood belonging.

\section{Mobility, policing, and race}

Traffic enforcement stops are the most common form of interaction between the police and the public in the United States. In 2015, over 53 million residents had some form of police contact. Roughly 62 percent of those contacts occurred while people were driving a vehicle, riding as a passenger in a vehicle, or as a result of traffic crash (Davis, Whyde, and Langton 2018). Put another way, about one in every eight drivers are stopped by the police every year (Epp, Maynard-Moody, and Haider-Markel 2014). But those stops are not equally distributed across the population; about twice as many, or one in four, Black drivers are stopped annually (Epp, Maynard-Moody, and Haider-Markel 2014).

Historians and legal scholars have argued that the proliferation of contact between police and everyday residents was singularly driven by interests related to the automobile. In the first instance, automobiles reordered who had rights to the road. Until about the 1920 s, there were few if any strict laws regulating street use. Pedestrians, horse-drawn carriages, bicycles, trams, and the few cars that existed all intermingled on city streets. ${ }^{2}$ As the automobile became more ubiquitous,

\footnotetext{
${ }^{2}$ One of the best illustrations of street use in that day is the short film "A Trip Down Market Street," shot in 1906. The film captures a scene from the perspective of a streetcar traveling down Market Street in San Francisco toward the ferry building, with horse-drawn carriages, pedestrians, bicycles, and cars all navigating the street together in the same space. Several restored and edited versions of the film are available online; one of them is at https://www.youtube.com/watch?v=8YRbMMqj0qw.
} 
however, and as the number of traffic crashes increased as a result, laws that had previously favored pedestrians shifted to ensure the smooth flow of automobiles, spearheaded by auto-interest groups. In short, these changes led to the invention and criminalization of jaywalking ${ }^{3}$ and shaped the hierarchy on the streets (Norton 2011).

While the proliferation of the automobile prompted changes in the way that street space was regulated, another profound change in policing came about with the way that courts viewed traffic stops with respect to constitutional rights. American jurisprudence came to see automobiles as conveying little privacy to individuals, cementing the right to privacy within one's home as legally different from a right to privacy on public roadways (Seo 2019). This lessened right to privacy extends to most stops in the public right of way and has led to extensive use of stop-and-friskthat is, a brief stop where police pat down a suspect if they have a reasonable suspicion of a crime having occurred-as a policing tool. Opponents of stop-and-frisk, such as the NAACP (the National Association for the Advancement of Colored People, the most prominent civil organization group in the US), warned of its consequences for Black people, borne out by the evidence of disproportionate application in cities like New York and Chicago (Fagan et al. 2009; Howell 2016; ACLU of Illinois 2015). Courts have also reasoned that officers should be given the benefit of the doubt as to what constitutes a legitimate traffic stop. Because nearly every vehicle action could be read as a violation of the law in some regard, the decision to pull over a vehicle is almost always within reason. While race cannot be used as the reason to initiate the stop, evidence of disparate racial impacts would not necessarily be enough to prevent stops. In other words, if the police wanted to profile individuals by race, they could - so long as the professed reason for the traffic stop was any violation of the vehicle code (Seo 2019; Baumgartner, Epp, and Shoub 2018).

Abundant evidence bears out the fact that people of color are stopped more often by the police (D. A. Harris 1999; Epp, Maynard-Moody, and Haider-Markel 2014; Warren et al. 2006; Pierson et al. 2020). Young Black men are taught how to deal with this reality when they drive, walk, or otherwise move about so as to not endanger their lives during an encounter (Gandbhir and Foster 2015). Evidence of difference is not necessarily evidence of bias, however, scholars have used a number of techniques to investigate the degree to which Black and Brown drivers are disproportionately subject to police scrutiny relative to their counterparts. One body of work has examined the initiation of the stops themselves. When they occur is important. In one study, Pierson et al. (2020) compiled a database of nearly 100 million traffic stops from over 50 state and municipal police departments. Black drivers were stopped more often than white drivers, while Latino drivers were stopped less often. To assess whether the differences in stop rates were evidence of bias, the researchers used an adjustment technique known as the "veil of darkness" by estimating the likelihood an individual was stopped, controlling for the time of day, under the assumption that officers who stop individuals at night cannot observe skin color as well they can

\footnotetext{
${ }^{3}$ Even the term jaywalking has classist undertones, being derived from the word "jay," a slang term for an ignorant or provincial person.
} 
during daylight hours. There was a substantial drop in the proportion of Black drivers stopped after dark, giving evidence for racial discrimination based on this test (Pierson et al. 2020).

For what reason the stops occur is also important. Police may stop drivers for either safety reasons, such as speeding or driving under the influence, or for discretionary reasons, such as a broken tail light or a lapsed registration, that do not have immediate safety consequences (Epp, MaynardMoody, and Haider-Markel 2014). Safety stops exhibit a lower incidence of discriminatory patterns compared to discretionary stops (Baumgartner, Epp, and Shoub 2018). When a police department in North Carolina shifted its traffic enforcement emphasis to safety stops in an effort to reduce serious motor vehicle crashes, both the total number of traffic stops and the ratio of stops involving Black drivers to white drivers decreased, as did the number of vehicle crashes (Fliss et al. 2020). Traffic stops have long been used as a crime deterrent as advocated by the "broken windows" theory of policing (J. Q. Wilson and Kelling 1982), a theory that posits that a preponderance of minor crimes like vandalism contribute to major ones, but the authors found that the number of crimes did not increase relative to control cities. The same logic applies to pedestrian and bicycle stops. Citations are disproportionately issued in Black and Latino neighborhoods and the vast majority are given minor infractions such as riding a bike on the sidewalk or walking along a roadway (Wisniewski 2018; Barajas 2019).

A second body of work has examined the outcomes of the stops; specifically, the likelihood with which drivers would be searched during the stop. The evidence for racial bias is convincing. Across 55 million traffic stops and in every state for which they had data, the racial disparities in who was searched were large and consistent. On average, Black drivers were searched twice as often as white or Latino drivers (Baumgartner et al. 2017). A study that focused on the 5 million traffic stops that occurred in Illinois and North Carolina found that Black and Latino drivers were searched more often than white drivers, and men in all racial and ethnic categories were searched than women, controlling for racial and socioeconomic neighborhood characteristics (Shoub et al. 2020). In another study of 20 million observations from Illinois examining both racial and gender characteristics of drivers, one researcher found that the higher the degree to which someone fit the profile of a young, Black, poor male, the more likely they were to have been searched after a traffic stop and the less likely they were to have received a warning instead of a citation (Christiani 2020). Finally, a study of 40 million police stops across four states found that Black men were more likely to be stopped and searched but less likely to be found with contraband, particularly when the stop was initiated for discretionary rather than safety reasons (Roach et al. 2020).

Latinos also face scrutiny on the streets, further complicated by immigration policy. Immigration restrictions have tightened in the wake of the increasing priority placed on counterterrorism efforts since September 11, 2001, although anti-immigrant narratives have persisted throughout US history. In several states, including Arizona, Mississippi, and Alabama, legislatures passed what colloquially have been called "show me your papers" laws, in which local police were empowered to ask people they stopped whether they were lawfully present in the United States. US Immigration and Customs Enforcement can establish memoranda of agreement with local and state 
law enforcement agencies to allow them to act as federal immigration officers when they detain individuals under the $287(\mathrm{~g})$ program. No matter the statues under which the police operate, the additional powers granted to police act to limit the mobility of all immigrants, documented or not, because of the racial profiling associated with such programs. Many undocumented immigrants fear leaving the home or alter their travel to avoid detection, resulting in lost opportunities, including work and access to health care (Stuesse and Coleman 2014; Toomey et al. 2014; Maldonado, Licona, and Hendricks 2016). Some of these policies may account for travel behavior differences, such as the lower likelihood of commuting by car among undocumented immigrants (Allen and Wang 2020).

\section{Safety and security}

Transportation safety research and practice is concerned with preventing collisions between vehicles and other vehicles, pedestrians, and cyclists. Historically, the solution to this problem has been to try to eliminate fatal consequences of inevitable human error via engineering countermeasures, for example, by creating "clear zones" devoid of fixed objects that drivers can crash into regardless of whether the road is a high-speed freeway or in an dense urban area (Dumbaugh and Gattis 2005). This sort of design, along with improvements in car safety standards, has reduced injury outcomes for drivers but has done little to nothing to reduce the danger for vulnerable road users (Noland 2003). In response, researchers and advocates have proposed an alternative approach known as "safe systems" that takes driver error into account by slowing speeds, encouraging safe behavior, and designing safe roads (Dumbaugh, Saha, and Merlin 2020). In practice, the safe systems approach is implemented as Vision Zero, first established in Sweden and subsequently adopted around the world, and shifts some of the onus for safety onto road system designers (Cushing et al. 2016).

The Vision Zero approach is also a data-driven approach to safety planning, wherein cities use information about the most dangerous traffic locations to prioritize interventions. Many Vision Zero cities find that a disproportionate number of high-crash intersections and corridors are in communities of color (City of Chicago 2017; City of Los Angeles 2015; City and County of San Francisco 2015), likely because of infrastructure disparities documented earlier. National-level statistics also bear out the disproportionate safety burden that people of color face (Figure 2). Black road users especially are overrepresented in pedestrian and bicycle fatalities relative to their share in the population, trips taken, and miles traveled using statistics from the two most recent national travel surveys, in 2009 and 2017. Likewise, the most dangerous corridors for pedestrians are in majority Black and Latino neighborhoods (Schneider et al. 2021). The reasons for these disparities include biases in infrastructure funding and implementation in communities of color and increased

vulnerability associated with personal travel, such as night-shift workers who travel during darkness and new immigrants who are not yet accustomed to US traffic norms (Cradock et al. 2009; Smith et al. 2017; Braun, Rodriguez, and Gordon-Larsen 2019; Chen, Lin, and Loo 2012; Yu 2014; M. L. Lee et al. 2016). 


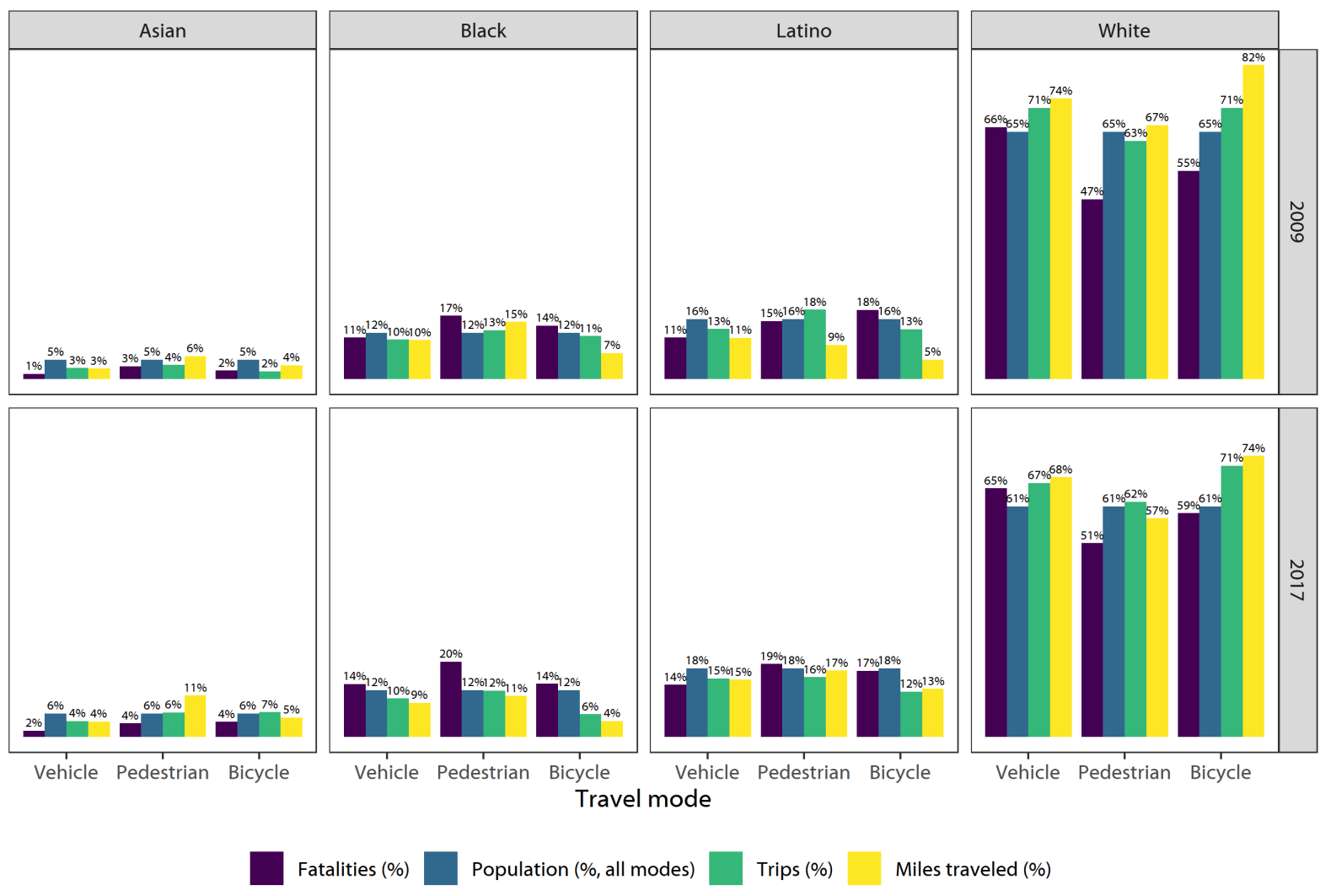

Figure 2: Share of road fatalities compared to population, trips made, and miles traveled by racelethnicity and year. Denominator excludes unidentified racelethnicity. Sources: National Highway Traffic Safety Administration (2019); U. S. Census Bureau (2020); Federal Highway Administration (2017)

But safety carries a double meaning. People in communities of color are often equally or more concerned with personal security, or safety from violence. Pedestrians and cyclists, who travel in "exposed" modes, may be at greatest risk (Appleyard and Ferrell 2017). A study of New Jersey residents in Black and Latino communities found that cyclists and non-cyclists alike rated fear of robbery or assault as the second-highest rated barrier to cycling after fear of traffic collisions (Brown 2016). In a study measuring the efficacy of a bicycle education and training program on overweight Black and Latino adults, researchers found that about two-thirds of participants rated fear of crime as a barrier to cycling. The intervention helped reduce that barrier relative to a control group in the short term, but after a longer term follow-up, the difference was no longer significant (Schneider et al. 2018). To counter potential danger from interpersonal violence, cyclists in lowincome communities and communities of color may adopt different cycling behaviors than cyclists in other communities, preferring to cycle on busier streets where they are most visible rather than on quieter streets that may be safer from traffic (Lusk et al. 2019).

Residents of communities of color and low-income communities also rate high crime as significant barriers to walking and accessing transit (Barajas 2020; Coren, Lowe, and Barajas 2021), and these 
barriers may be even higher for women and gender non-conforming individuals (Loukaitou-Sideris et al. 2020; Lubitow, Abelson, and Carpenter 2020). An educational intervention in which participants learned about systemic strategies for improving pedestrian safety found no change in perceptions of crime as barriers to walking in the short-term; roughly 60 percent of participants described danger from crime as a barrier to walking both before and after the workshop (Barajas et al. 2019). Interpersonal violence compounds the danger from the ever-present street violence, creating even greater vulnerabilities for those who have few other options to walking or cycling (Lachapelle and Noland 2015). The possibilities of danger are particularly salient for youth of color. While planning research and practice tends to emphasize changes in the built environment to promote walkability and safe routes to school, young students describe shootings, gang members, and "broken windows"-type disorder as significant barriers to walking to school in inner-city neighborhoods (Banerjee, Uhm, and Bahl 2014; Webb Jamme, Bahl, and Banerjee 2018).

\section{Neighborhood context: Othering and belonging}

While feelings of insecurity arise from crime rates and the danger of the unknown, barriers to travel also exist for people who draw suspicion because they are judged not to belong in a particular place. One explanation for the pervasive nature of racial profiling in police stops is the racial threat hypothesis. The hypothesis suggests that elites seek to impose greater control on the Black population as it grows because of the political, economic, and criminal threats they pose (e.g. Eitle, D'Alessio, and Stolzenberg 2002). In some places, there is evidence that this theory may hold for traffic stops, where more stops occur in areas with more Black or Latino residents (Ingram 2007; Roh and Robinson 2009). But others have found compelling evidence for a different "race-out-ofplace" theory, in which drivers who are assumed to be interlopers to the neighborhood are treated as more suspect. Scholars have found that Black drivers are more likely to be stopped in predominately white neighborhoods and vice versa for white drivers (Novak and Chamlin 2012; Rojek, Rosenfeld, and Decker 2012). An version of this theory grounded in economics is the postindustrial policing thesis, which suggests that gentrifying neighborhoods or cities with growing creative class economies will increase social order policing for relatively minor infractions of the law (Sharp 2014; Laniyonu 2018; Newberry 2020).

The implications of not belonging in a neighborhood are increased surveillance of people of color by both police and private citizens on the one hand, and their suspicion of planning efforts on the other, heightened by the twin concerns of gentrification and displacement. Particularly with respect to cycling and recreational facilities, communities of color have viewed new infrastructure with skepticism because they perceive the investment to have come only after economic redevelopment of their neighborhoods had begun (Lubitow and Miller 2013; Hoffmann and Lugo 2014). Mainstream bicycle advocacy, too, has promoted cycling from the perspective of the young, middle-class, white professional returning to the city, while ignoring the circumstances of people of color and laborers who have relied on cycling in the absence of safe infrastructure (Sheller 2015; Hoffmann 2016; Lugo 2018). These histories have manifested in differences in the use of such 
facilities. Marginalized cyclists, for example, have substituted "human infrastructure," or their accumulated knowledge of and experiences with the city, to navigate when hard infrastructure was non-existent, relying on paths they know to be safe even if designated routes were built (Lugo 2013). In the case of new recreational facilities, people of color who cycle or walk along paths self-segregate away from gentrifying neighborhoods to avoid inviting suspicion and run-ins with the police (B. Harris, Rigolon, and Fernandez 2020; B. Harris et al. 2020).

The perception of non-auto users as "others" is also evident in public transit in the United States. There are both income and race divides both between public transit riders and users of other modes and within public transit modes themselves. Data from the 2017 National Household Travel Survey show that transit riders are on the whole poorer than users of other modes, while bus riders have a median household income below poverty wages compared to six-figure household incomes for rail riders. The majority of transit riders are people of color, compared to less than half of all other modes. Again, there are stark differences between bus riders and rail riders: people of color make up almost three-quarters of bus riders, compared to almost one-half of subway and light-rail riders and one-third of commuter rail riders (Federal Highway Administration 2017). These demographic patterns are hard to disentangle from a general stigma against public transportation (Schweitzer 2014); some neighborhood residents oppose new transit service because they fear the "other" who rides it (Weitz 2008), while transit riders of color themselves perceive discrimination on the part of other riders or transit officials as barriers to use (Liu and Schachter 2007; Lubitow, Rainer, and Bassett 2017; Barajas, Agrawal, and Chatman 2018).

\section{Conclusions and policy implications}

A long history of racist practices, including individual discrimination and systemic exclusion from the right to safe and free movement via government policy, has led to profound disparities in the benefits and burdens of transportation for people of color in the United States. One can trace how questions of mobility, transportation, and race have been intertwined across eras-from colonial settlement through slavery and Jim Crow to the civil rights movement and beyond to modern-day urban and transportation planning - and observe how that has placed limits on access and opportunity for marginalized people. This history also gives perspective on how policing, insecurity, and othering work to limit the mobility of people of color. The effects of distributional inequities together with policing are lost economic opportunities, poor health outcomes, and even death in "arrested mobility" (Brown 2021) for Black people and other people of color. Taken together, the links between history, planning, and policing also give context for why race and racism is a fundamental determinant of travel behavior. Focusing on race and racism in transportation research and practice helps guide how to approach achieving a more just transportation system.

First, it is important to account for race not just as a control variable in transportation models, but to center it in analysis to appropriately account for its effects on travel behavior. This includes 
incorporating information about racial identity in any models that are used to support planning and policy efforts. It also includes identifying how information about race is specified. The way we measure and interpret race can change how we fundamentally understand the relationships between measurement and outcome. For example, when analyzing effects of race, default comparisons to a white reference population reproduces the notion that white groups are the norm (Johfre and Freese 2021). Point estimates of impacts without attention to the distribution of those impacts can lead to misleading results and can misstate the effects of inventions across populations of concern (Bills and Walker 2017). In some cases, such as traffic collisions, race information is not always collected or not released, making it impossible to make claims about or assign remedies to unjust conditions. As new data sources proliferate, it is important to understand how the data points are collected or contributed and to acknowledge and address the inherent biases prior to allowing them to guide decisions (Williams 2020). And while proper quantitative data about race can aid in better decision making, it is important to remember that not all data can be captured by numbers-lived experiences are valid qualitative data points-and that analysts' own positionalities contribute biases and errors in the research and modeling process (Lowe 2020).

Second, adopting a broader perspective about equity and justice is fundamental to achieving fairer transportation systems. The history described earlier helps convey why transportation inequity is more than a problem of benefits and burdens, and why some theories of transportation justice that focus on individuals and on access alone fall short. Mobility justice requires more than just ensuring equal distribution of infrastructure, resources, and service; it "calls for recognition, participation, deliberation, and procedural fairness to be up for discussion, adjustment, and repair" (Sheller 2018,28). Advocates of mobility justice in transportation practice encourage planners and decision-makers to reckon with history, to value community experience and knowledge, and to recognize that identity is linked to vulnerability (Untokening Collective 2017). Transportation planning built on such principles requires fundamental shifts in the relationship between governments and communities, moving beyond perfunctory community engagement and working on solutions that prioritize equitable outcomes over mere mitigation of existing inequalities and findings of no disparate impact.

Finally, a focus on race in transportation highlights the need to work outside of professional silos to recognize how other domains affect travel and how policies to improve or enhance transportation may have unintended consequences. For example, many plans that seek to improve transportation safety rely on traffic enforcement as a fundamental component of the overall strategy (e.g. City of Chicago 2017). But any policy that calls for additional policing places people of color - and Black people especially - at disproportionate risk despite the benefits from crash reductions. Some efforts are beginning to walk back the role of police in safety after a greater attention to racial injustice in the United States was sparked in the summer 2020 protests; national policy advocates have called for replacing additional traffic enforcement with more safely designed streets (Shahum 2020; Transportation Alternatives 2020), the state of Virginia has taken steps to decriminalize jaywalking (K. Wilson 2021), and several US cities are reforming the way 
the police are involved in traffic stops. More recently, connections between transportation and public health professionals have been strengthened; stronger links between transportation and community development may also produce stronger conditions for transportation justice.

\section{Acknowledgments}

Many thanks to Miriam Solis, Geneviève Boisjoly, and Rafael H. M. Pereira for their invaluable critiques and comments.

\section{References}

ACLU of Illinois. 2015. "Stop and Frisk in Chicago." https://www.acluil.org/sites/default/files/wp-content/uploads/2015/03/ACLU_StopandFrisk_6.pdf.

Adkins, Arlie, Carrie Makarewicz, Michele Scanze, Maia Ingram, and Gretchen Luhr. 2017. "Contextualizing Walkability: Do Relationships Between Built Environments and Walking Vary by Socioeconomic Context?" Journal of the American Planning Association 83 (3): 296-314. https://doi.org/10.1080/01944363.2017.1322527.

Ajzen, Icek. 1991. "The Theory of Planned Behavior." Organizational Behavior and Human Decision Processes, Theories of Cognitive Self-Regulation, 50 (2): 179-211. https://doi.org/10.1016/0749-5978(91)90020-T.

Allen, Ryan, and Jueyu Wang. 2020. "Immigrant Legal Status and Commute Mode Choice for Hispanics in the United States." Journal of the American Planning Association 0 (0): 1-13. https://doi.org/10.1080/01944363.2020.1724818.

Appleyard, Bruce S., and Christopher E. Ferrell. 2017. "The Influence of Crime on Active \& Sustainable Travel: New Geo-Statistical Methods and Theories for Understanding Crime and Mode Choice." Journal of Transport \& Health 6 (September): 516-29. https://doi.org/10.1016/j.jth.2017.04.002.

Arsenault, Raymond. 2006. Freedom Riders: 1961 and the Struggle for Racial Justice. Pivotal Moments in American History. Oxford ; New York: Oxford University Press.

Avila, Eric. 2014. The Folklore of the Freeway: Race and Revolt in the Modernist City. A Quadrant Book. Minneapolis: University of Minnesota Press.

Ayres, Ian, and Peter Siegelman. 1995. "Race and Gender Discrimination in Bargaining for a New Car." The American Economic Review 85 (3): 304-21. https://www.jstor.org/stable/2118176.

Banerjee, Tridib, JungA Uhm, and Deepak Bahl. 2014. "Walking to School: The Experience of Children in Inner City Los Angeles and Implications for Policy." Journal of Planning Education and Research 34 (2): 123-40. https://doi.org/10.1177/0739456X14522494. 
Barajas, Jesus M. 2016. "Making Invisible Riders Visible: Motivations for Bicycling and Public Transit Use Among Latino Immigrants." Dissertation, Berkeley, CA: University of California, Berkeley.

2019. "Traffic Citations in Chicago: Implications for Pedestrian and Bicycle Equity." presented at the 49th Urban Affairs Association Conference, Los Angeles, April 25.

- 2020. "Supplemental Infrastructure: How Community Networks and Immigrant Identity Influence Cycling." Transportation 47 (June): 1251-74. https://doi.org/10.1007/s11116-0189955-7.

Barajas, Jesus M., Asha Weinstein Agrawal, and Daniel G. Chatman. 2018. "Immigration, Income, and Public Transit Perceptions: Findings from an Intercept Survey." Journal of Public Transportation 21 (2): 1-18. https://doi.org/https://doi.org/10.5038/2375-0901.21.2.1.

Barajas, Jesus M., Kate M. Beck, Jill F. Cooper, Ana Lopez, and Amanda Reynosa. 2019. "How Effective Are Community Pedestrian Safety Training Workshops? Short-Term Findings from a Program in California." Journal of Transport \& Health 12 (March): 183-94. https://doi.org/10.1016/j.jth.2019.01.002.

Bastiaanssen, Jeroen, Daniel Johnson, and Karen Lucas. 2020. "Does Transport Help People to Gain Employment? A Systematic Review and Meta-Analysis of the Empirical Evidence." Transport Reviews 0 (0): 1-22. https://doi.org/10.1080/01441647.2020.1747569.

Baumgartner, Frank R., Leah Christiani, Derek A. Epp, Kevin Roach, and Kelsey Shoub. 2017. "Racial Disparities in Traffic Stop Outcomes." Duke Forum for Law and Social Change 9: 21-54. https://heinonline.org/HOL/P?h=hein.journals/dukef9\&i=22.

Baumgartner, Frank R., Derek A. Epp, and Kelsey Shoub. 2018. Suspect citizens: what 20 million traffic stops us about policing and race. https://public.ebookcentral.proquest.com/choice/publicfullrecord.aspx?p=5473139.

Ben-Akiva, Moshe, and Steven R. Lerman. 1985. Discrete Choice Analysis: Theory and Application to Travel Demand. Cambridge, MA: MIT Press.

Bierbaum, Ariel H., Alex Karner, and Jesus M. Barajas. 2020. "Toward Mobility Justice: Linking Transportation and Education Equity in the Context of School Choice." Journal of the American Planning Association 0 (0): 1-14. https://doi.org/10.1080/01944363.2020.1803104.

Bills, Tierra S., and Joan L. Walker. 2017. "Looking Beyond the Mean for Equity Analysis: Examining Distributional Impacts of Transportation Improvements." Transport Policy 54 (February): 61-69. https://doi.org/10.1016/j.tranpol.2016.08.003.

Braun, Lindsay M., Daniel A. Rodriguez, and Penny Gordon-Larsen. 2019. "Social (in)equity in Access to Cycling Infrastructure: Cross-Sectional Associations Between Bike Lanes and Area- 
Level Sociodemographic Characteristics in 22 Large U.S. Cities." Journal of Transport Geography 80 (October): 102544. https://doi.org/10.1016/j.jtrangeo.2019.102544.

Brown, Charles T. 2016. "Fear: A Silent Barrier to Bicycling in Black and Brown Communities." ITE Journal, September 2016. https://nacto.org/wp-content/uploads/2017/03/2016_Brown_FearA-Silent-Barrier-to-Bicycling-in-Black-and-Hispanic-Communities.pdf.

_. 2021. "Arrested Mobility." Presented at the 100th Annual Meeting of the Transportation Research Board, January 25.

Bullard, Robert D. 2004. "The Anatomy of Transportation Racism." In Highway Robbery, edited by Robert D. Bullard, Glenn S. Johnson, and Angel O. Torres, 15-32. South End Press.

Bullard, Robert D., Glenn S. Johnson, and Angel O. Torres. 2004. "Dismantling Transit Racism in Metro Atlanta." In Highway Robbery, edited by Robert D. Bullard, Glenn S. Johnson, and Angel O. Torres, 49-73. South End Press.

Campanella, Thomas J. 2017. "The True Measure of Robert Moses (and His Racist Bridges)." Bloomberg CityLab. July 9, 2017. https://www.bloomberg.com/news/articles/2017-07-09/robertmoses-and-his-racist-parkway-explained.

Campbell, Stanley W. 1970. The Slave Catchers: Enforcement of the Fugitive Slave Law, 18501860. Chapel Hill: University of North Carolina Press.

Caro, Robert A. 1975. The Power Broker: Robert Moses and the Fall of New York. New York: Vintage Books.

Carpio, Genevieve. 2019. Collisions at the Crossroads: How Place and Mobility Make Race. Oakland, California: University of California Press.

Chen, Cynthia, Haiyun Lin, and Becky PY Loo. 2012. "Exploring the Impacts of Safety Culture on Immigrants' Vulnerability in Non-Motorized Crashes: A Cross-Sectional Study." Journal of Urban Health 89 (1): 138-52. https://doi.org/10.1007/s11524-011-9629-7.

Christiani, Leah. 2020. "Intersectional Stereotyping in Policing: An Analysis of Traffic Stop Outcomes." Politics, Groups, and Identities $0 \quad(0)$ : 1-23. https://doi.org/10.1080/21565503.2020.1748064.

City and County of San Francisco. 2015. "Vision Zero San Francisco Two-Year Action Strategy." San Francisco.

City of Chicago. 2017. "Vision Zero Chicago Action Plan 2017-2019." http://visionzerochicago.org/wp-content/uploads/2016/05/17_0612-VZ-Action-Plan_FORWEB.pdf. 
City of Los Angeles. 2015. "Vision Zero Los Angeles: 2015--2025.” Los Angeles.

Coren, Chelsie, Kate Lowe, and Jesus M. Barajas. 2021. "Commuting in Context: A Qualitative Study of Transportation Challenges for Disadvantaged Job Seekers in Chicago, IL." In. Washington, D.C.

Cradock, Angie L., Philip J. Troped, Billy Fields, Steven J. Melly, Shannon V. Simms, Franz Gimmler, and Marianne Fowler. 2009. "Factors Associated with Federal Transportation Funding for Local Pedestrian and Bicycle Programming and Facilities." Journal of Public Health Policy 30 (S1): S38-72. https://doi.org/10.1057/jphp.2008.60.

Cushing, Matthew, Jonathan Hooshmand, Bryan Pomares, and Gillian Hotz. 2016. "Vision Zero in the United States Versus Sweden: Infrastructure Improvement for Cycling Safety." American Journal of Public Health, October, e1-3. https://doi.org/10.2105/AJPH.2016.303466.

Dargay, Joyce, Dermot Gately, and Martin Sommer. 2007. "Vehicle Ownership and Income Growth, Worldwide: 1960-2030." The Energy Journal 28 (4). https://doi.org/10.5547/ISSN01956574-EJ-Vol28-No4-7.

Davis, Elizabeth, Anthony Whyde, and Lynn Langton. 2018. "Contacts Between Police and the Public, 2015.” NCJ 251145. Washington, D.C.: US Department of Justice.

Ding, Hao, Anastasia Loukaitou-Sideris, and Asha Weinstein Agrawal. 2020. "Sexual Harassment and Assault in Transit Environments: A Review of the English-Language Literature." Journal of Planning Literature, March, 0885412220911129. https://doi.org/10.1177/0885412220911129.

Dumbaugh, Eric, and J. L. Gattis. 2005. "Safe Streets, Livable Streets." Journal of the American Planning Association 71 (3): 283-300. https://doi.org/10.1080/01944360508976699.

Dumbaugh, Eric, Dibakar Saha, and Louis Merlin. 2020. "Toward Safe Systems: Traffic Safety, Cognition, and the Built Environment." Journal of Planning Education and Research, August, 0739456X20931915. https://doi.org/10.1177/0739456X20931915.

Dunbar-Ortiz, Roxanne. 2014. An indigenous peoples' history of the United States. Boston: Beacon Press.

Eitle, David, Stewart J D'Alessio, and Lisa Stolzenberg. 2002. "Racial Threat and Social Control: A Test of The Political, Economic, and Threat of Black Crime Hypotheses." Social Forces 81 (2): 557-76. https://doi.org/10.1353/sof.2003.0007.

Epp, Charles R., Steven Maynard-Moody, and Donald P. Haider-Markel. 2014. Pulled over: How Police Stops Define Race and Citizenship. The Chicago Series in Law and Society. Chicago; London: The University of Chicago Press. 
Fagan, Jeffrey, Amanda Geller, Garth Davies, and Valerie West. 2009. "Street Stops and Broken Windows Revisited: The Demography and Logic of Proactive Policing in a Safe and Changing City." In Race, Ethnicity, and Policing: New and Essential Readings, edited by Stephen K. Rice and Michael D. White. NYU Press. https://papers.ssrn.com/abstract=1399073.

Federal Highway Administration. 2017. "National Household Travel Survey." https://nhts.ornl.gov.

Flanagan, Elizabeth, Ugo Lachapelle, and Ahmed El-Geneidy. 2016. "Riding Tandem: Does Cycling Infrastructure Investment Mirror Gentrification and Privilege in Portland, OR and Chicago, IL?" Research in Transportation Economics, Transportation and Land Development: A Global View, 60 (December): 14-24. https://doi.org/10.1016/j.retrec.2016.07.027.

Fliss, Mike Dolan, Frank R. Baumgartner, Paul Delamater, Steve Marshall, Charles Poole, and Whitney Robinson. 2020. "Re-Prioritizing Traffic Stops to Reduce Motor Vehicle Crash Outcomes and Racial Disparities." Injury Epidemiology 7 (1): 3. https://doi.org/10.1186/s40621019-0227-6.

Gandbhir, Geeta, and Blair Foster, dirs. 2015. A Conversation With My Black Son. The New York Times. https://www.nytimes.com/video/opinion/100000003575589/a-conversation-with-myblack-son.html.

García, Ivis. 2020. "Cultural Insights for Planners: Understanding the Terms Hispanic, Latino, and Latinx." Journal of the American Planning Association 86 (4): 393-402. https://doi.org/10.1080/01944363.2020.1758191.

Garrett, Mark, and Brian Taylor. 1999. "Reconsidering Social Equity in Public Transit." Berkeley Planning Journal 13 (1). https://escholarship.org/uc/item/1 mc9t108.

Golub, Aaron, Richard A. Marcantonio, and Thomas W. Sanchez. 2013. "Race, Space, and Struggles for Mobility: Transportation Impacts on African Americans in Oakland and the East Bay.” Urban Geography 34 (5): 699-728. https://doi.org/10.1080/02723638.2013.778598.

Grengs, Joe. 2005. "The Abandoned Social Goals of Public Transit in the Neoliberal City of the USA.” City 9 (1): 51-66. https://doi.org/10.1080/13604810500050161.

— 2012. "Equity and the Social Distribution of Job Accessibility in Detroit." Environment and Planning B: Planning and Design 39 (5): 785-800. https://doi.org/10.1068/b36097.

Handy, Susan, and Yan Xing. 2011. "Factors Correlated with Bicycle Commuting: A Study in Six Small U.S. Cities." International Journal of Sustainable Transportation 5 (2): 91-110. https://doi.org/10.1080/15568310903514789. 
Harris, Brandon, Alessandro Rigolon, and Mariela Fernandez. 2020. “'To Them, We're Just Kids from the Hood': Citizen-Based Policing of Youth of Color, 'White Space,' and Environmental Gentrification.” Cities 107 (December): 102885. https://doi.org/10.1016/j.cities.2020.102885.

Harris, Brandon, Dorothy Schmalz, Lincoln Larson, Mariela Fernandez, and Sarah Griffin. 2020. "Contested Spaces: Intimate Segregation and Environmental Gentrification on Chicago's 606 Trail." City \& Community 19 (4): 933-62. https://doi.org/https://doi.org/10.1111/cico.12422.

Harris, David A. 1999. "The Stories, the Statistics, and the Law: Why Driving While Black Matters.” Minnesota Law Review 84: 265-326.

Hoffmann, Melody L. 2016. Bike Lanes Are White Lanes: Bicycle Advocacy and Urban Planning. Lincoln: University of Nebraska Press.

Hoffmann, Melody L., and Adonia E. Lugo. 2014. “Who Is 'World Class'? Transportation Justice and Bicycle Policy." Urbanities 4 (1): 45-61. http://www.anthrojournalurbanities.com/docs/tableofcontents_6/5-\%20Hoffmann-Lugo.pdf.

Howell, K. Babe. 2016. "The Costs of Broken Windows Policing: Twenty Years and Counting." Cardozo L. Rev. 37 (3): 1059-73.

Ihlanfeldt, Keith R., and David L. Sjoquist. 1998. "The Spatial Mismatch Hypothesis: A Review of Recent Studies and Their Implications for Welfare Reform." Housing Policy Debate 9 (4): 84992. https://doi.org/10.1080/10511482.1998.9521321.

Ingram, Jason R. 2007. "The Effect of Neighborhood Characteristics on Traffic Citation Practices of the Police." Police Quarterly 10 (4): 371-93. https://doi.org/10.1177/1098611107306995.

Jackson, Kenneth. 1985. Crabgrass Frontier: The Suburbanization of the United States. New York: Oxford University Press.

Johfre, Sasha Shen, and Jeremy Freese. 2021. "Reconsidering the Reference Category." Sociological Methodology, January, 0081175020982632. https://doi.org/10.1177/0081175020982632.

Karner, Alex, and Richard Duckworth. 2019. "'Pray for Transit': Seeking Transportation Justice in Metropolitan Atlanta." Urban Studies $56 \quad$ (9): 1882-1900. https://doi.org/10.1177/0042098018779756.

Karner, Alex, Jonathan London, Dana Rowangould, and Kevin Manaugh. 2020. "From Transportation Equity to Transportation Justice: Within, Through, and Beyond the State." Journal of Planning Literature, May, 0885412220927691. https://doi.org/10.1177/0885412220927691. 
Karner, Alex, and Deb Niemeier. 2013. "Civil Rights Guidance and Equity Analysis Methods for Regional Transportation Plans: A Critical Review of Literature and Practice." Journal of Transport Geography 33 (December): 126-34. https://doi.org/10.1016/j.jtrangeo.2013.09.017.

Karner, Alex, Dana Rowangould, and Jonathan London. 2016. "We Can Get There From Here: New Perspectives on Transportation Equity." Davis, CA: National Center for Sustainable Transportation. https://ncst.ucdavis.edu/wp-content/uploads/2016/12/NCST_EquityWhitePaperFINAL.pdf.

Krapp, Agustina, Jesus M. Barajas, and Audrey Wennink. 2021. "Equity-Oriented Criteria for Project Prioritization in Regional Transportation Planning." In.

Lachapelle, Ugo, and Robert B. Noland. 2015. "Inconsistencies in Associations Between Crime and Walking: A Reflection of Poverty and Density." International Journal of Sustainable Transportation 9 (2): 103-15. https://doi.org/10.1080/15568318.2012.742947.

Laniyonu, Ayobami. 2018. "Coffee Shops and Street Stops: Policing Practices in Gentrifying Neighborhoods:" Urban Affairs Review $54 \quad$ (4): $898-930$. https://doi.org/10.1177/1078087416689728.

Lee, Michael L., Mark E. Howard, William J. Horrey, Yulan Liang, Clare Anderson, Michael S. Shreeve, Conor S. O'Brien, and Charles A. Czeisler. 2016. "High Risk of Near-Crash Driving Events Following Night-Shift Work." Proceedings of the National Academy of Sciences 113 (1): 176-81. https://doi.org/10.1073/pnas.1510383112.

Lee, Richard J., Ipek N. Sener, and S. Nathan Jones. 2017. "Understanding the Role of Equity in Active Transportation Planning in the United States." Transport Reviews 37 (2): 211-26. https://doi.org/10.1080/01441647.2016.1239660.

Levine, Jonathan, Joe Grengs, and Louis A. Merlin. 2019. From Mobility to Accessibility: Transforming Urban Transportation and Land-Use Planning. Ithaca [New York]: Cornell University Press.

Lewis, Tom. 2013. Divided Highways: Building the Interstate Highways, Transforming American Life. Ithaca, NY: Cornell University Press.

Liu, Rongfang (Rachel), and Hindy Lauer Schachter. 2007. "Mobility Information Needs of Immigrants with Limited English Proficiency (LEP) in New Jersey." Journal of Immigrant \& Refugee Studies 5 (2): 89-108. https://doi.org/10.1300/J500v05n02_05.

Loukaitou-Sideris, Anastasia, Madeline Brozen, Miriam Pinski, and Hao Ding. 2020. "Documenting \#MeToo in Public Transportation: Sexual Harassment Experiences of University Students in Los Angeles." Journal of Planning Education and Research, September, 0739456X20960778. https://doi.org/10.1177/0739456X20960778. 
Lowe, Kate. 2020. "Undone Science, Funding, and Positionality in Transportation Research." Transport Reviews 0 (0): 1-18. https://doi.org/10.1080/01441647.2020.1829742.

Lubitow, Amy, Miriam J. Abelson, and Erika Carpenter. 2020. "Transforming Mobility Justice: Gendered Harassment and Violence on Transit." Journal of Transport Geography 82 (January): 102601. https://doi.org/10.1016/j.jtrangeo.2019.102601.

Lubitow, Amy, and Thaddeus R. Miller. 2013. "Contesting Sustainability: Bikes, Race, and Politics in Portlandia." Environmental Justice $6 \quad$ (4): 121-26. https://doi.org/10.1089/env.2013.0018.

Lubitow, Amy, Jennifer Rainer, and Sasha Bassett. 2017. "Exclusion and Vulnerability on Public Transit: Experiences of Transit Dependent Riders in Portland, Oregon.” Mobilities 12 (6): 924 37. https://doi.org/10.1080/17450101.2016.1253816.

Lubitow, Amy, Bryan Zinschlag, and Nathan Rochester. 2016. "Plans for Pavement or for People? The Politics of Bike Lanes on the 'Paseo Boricua' in Chicago, Illinois." Urban Studies 53 (12): 2637-53. https://doi.org/10.1177/0042098015592823.

Lugo, Adonia E. 2013. "CicLAvia and Human Infrastructure in Los Angeles: Ethnographic Experiments in Equitable Bike Planning." Journal of Transport Geography 30: 202-7. https://doi.org/10.1016/j.jtrangeo.2013.04.010.

- 2018. Bicycle/race: transportation, culture \& resistance. https://search.ebscohost.com/login.aspx?direct=true\&scope=site\&db=nlebk\&db=nlabk\&AN=21 82760 .

Lusk, Anne C., Walter C. Willett, Vivien Morris, Christopher Byner, and Yanping Li. 2019. "Bicycle Facilities Safest from Crime and Crashes: Perceptions of Residents Familiar with Higher Crime/Lower Income Neighborhoods in Boston." International Journal of Environmental Research and Public Health 16 (3): 484. https://doi.org/10.3390/ijerph16030484.

Maldonado, Marta Maria, Adela C. Licona, and Sarah Hendricks. 2016. "Latin@ Immobilities and Altermobilities Within the U.S. Deportability Regime." Annals of the American Association of Geographers 106 (2): 321-29. https://doi.org/10.1080/00045608.2015.1106304.

Manaugh, Kevin, Madhav G. Badami, and Ahmed M. El-Geneidy. 2015. "Integrating Social Equity into Urban Transportation Planning: A Critical Evaluation of Equity Objectives and Measures in Transportation Plans in North America." Transport Policy 37 (January): 167-76. https://doi.org/10.1016/j.tranpol.2014.09.013.

Mann, Eric. 2004. "Los Angeles Bus Riders Derail the MTA." In Highway Robbery, edited by Robert D. Bullard, Glenn S. Johnson, and Angel O. Torres, 33-48. South End Press. 
Marcantonio, Richard A., Aaron Golub, Alex Karner, and Louise Nelson. 2017. "Confronting Inequality in Metropolitan Regions: Realizing the Promise of Civil Rights and Environmental Justice in Metropolitan Transportation Planning." Fordham Urban Law Journal 44 (4): 1017. https:/ir.lawnet.fordham.edu/ulj/vol44/iss4/4.

Martens, Karel. 2017. Transport Justice: Designing Fair Transportation Systems. New York, NY: Routledge, Taylor \& Francis Group.

Martens, Karel, and Aaron Golub. 2018. "A Fair Distribution of Accessibility: Interpreting Civil Rights Regulations for Regional Transportation Plans." Journal of Planning Education and Research, September, 0739456X18791014. https://doi.org/10.1177/0739456X18791014.

Martens, Karel, Aaron Golub, and Glenn Robinson. 2012. "A Justice-Theoretic Approach to the Distribution of Transportation Benefits: Implications for Transportation Planning Practice in the United States." Transportation Research Part A: Policy and Practice 46 (4): 684-95. https://doi.org/10.1016/j.tra.2012.01.004.

McGurty, Eileen Maura. 2000. "Warren County, NC, and the Emergence of the Environmental Justice Movement: Unlikely Coalitions and Shared Meanings in Local Collective Action." Society \& Natural Resources 13 (4): 373-87. https://doi.org/10.1080/089419200279027.

Meyer, Michael D., and Eric J. Miller. 2001. Urban Transportation Planning. 2nd ed. McGrawHill.

Mohl, Raymond A. 2004. "Stop the Road: Freeway Revolts in American Cities." Journal of Urban History 30 (5): 674-706. https://doi.org/10.1177/0096144204265180.

Moody, Joanna, and Jinhua Zhao. 2020. "Travel Behavior as a Driver of Attitude: Car Use and Car Pride in U.S. Cities." Transportation Research Part F: Traffic Psychology and Behaviour 74 (October): 225-36. https://doi.org/10.1016/j.trf.2020.08.021.Moore-Monroy, Martha, Ada Wilkinson-Lee, Donna Lewandowski, and Alexandra Armenta. 2016. "No Hay Peor Lucha Que La Que No Se Hace: Re-Negotiating Cycling in a Latino Community." In Bicycle Justice and Urban Transformation: Biking for All?, edited by Aaron Golub, Melody L. Hoffman, Adonia E. Lugo, and Gerardo F. Sandoval. Routledge Equity, Justice and the Sustainable City. New York, NY: Routledge.

Mueller, Natalie, David Rojas-Rueda, Tom Cole-Hunter, Audrey de Nazelle, Evi Dons, Regine Gerike, Thomas Götschi, Luc Int Panis, Sonja Kahlmeier, and Mark Nieuwenhuijsen. 2015. "Health Impact Assessment of Active Transportation: A Systematic Review." Preventive Medicine 76 (July): 103-14. https://doi.org/10.1016/j.ypmed.2015.04.010.

National Highway Traffic Safety Administration. 2019. "Fatality Analysis Reporting System (FARS)." https://www.nhtsa.gov/research-data/fatality-analysis-reporting-system-fars. 
Nelson, Robert K., LaDale Winling, Richard Marciano, and Nathan Connolly. n.d. "Mapping Inequality: Redlining in New Deal America." Accessed January 7, 2021. https://dsl.richmond.edu/panorama/redlining/.

Newberry, Jay L. 2020. "Policing Strategies and Potential Targets: The Influence of Gentrification and Crime on the Stoppage of Blacks and Hispanics in New York City." Papers in Applied Geography 0 (0): 1-16. https://doi.org/10.1080/23754931.2020.1814848.

Noland, Robert B. 2003. "Traffic Fatalities and Injuries: The Effect of Changes in Infrastructure and Other Trends." Accident Analysis \& Prevention 35 (4): 599-611. https://doi.org/10.1016/S0001-4575(02)00040-4.

Norton, Peter D. 2011. Fighting traffic: the dawn of the motor age in the American city. Inside technology. Cambridge, Mass. London: MIT Press.

Novak, Kenneth J., and Mitchell B. Chamlin. 2012. "Racial Threat, Suspicion, and Police Behavior: The Impact of Race and Place in Traffic Enforcement." Crime \& Delinquency 58 (2): 275-300. https://doi.org/10.1177/0011128708322943.

Padeiro, Miguel, Ana Louro, and Nuno Marques da Costa. 2019. "Transit-Oriented Development and Gentrification: A Systematic Review." Transport Reviews 39 (6): 733-54. https://doi.org/10.1080/01441647.2019.1649316.

Pereira, Rafael H. M., and Alex Karner. 2021. "Transportation Equity." In International Encyclopedia of Transportation, edited by Roger Vickerman, 1st ed. Elsevier Science.

Pereira, Rafael H. M., Tim Schwanen, and David Banister. 2017. "Distributive Justice and Equity in Transportation." Transport Reviews $37 \quad$ (2): 170-91. https://doi.org/10.1080/01441647.2016.1257660.

Pierson, Emma, Camelia Simoiu, Jan Overgoor, Sam Corbett-Davies, Daniel Jenson, Amy Shoemaker, Vignesh Ramachandran, et al. 2020. "A Large-Scale Analysis of Racial Disparities in Police Stops Across the United States." Nature Human Behaviour 4 (7): 736-45. https://doi.org/10.1038/s41562-020-0858-1.

Pulido, Laura. 2017. "Geographies of Race and Ethnicity II: Environmental Racism, Racial Capitalism and State-Sanctioned Violence." Progress in Human Geography 41 (4): 524-33. https://doi.org/10.1177/0309132516646495.

Rice, Lisa, and Erich Schwartz, Jr. 2018. "Discrimination When Buying a Car: How the Color of Your Skin Can Affect Your Car-Shopping Experience." Washington, DC: National Fair Housing Alliance. https://nationalfairhousing.org/wp-content/uploads/2018/01/Discrimination-WhenBuying-a-Car-FINAL-1-11-2018.pdf. 
Roach, Kevin, Frank R. Baumgartner, Leah Christiani, Derek A. Epp, and Kelsey Shoub. 2020. "At the Intersection: Race, Gender, and Discretion in Police Traffic Stop Outcomes." Journal of Race, Ethnicity and Politics, 1-23. https://doi.org/10.1017/rep.2020.35.

Roh, Sunghoon, and Matthew Robinson. 2009. "A Geographic Approach to Racial Profiling: The Microanalysis and Macroanalysis of Racial Disparity in Traffic Stops." Police Quarterly, March. https://oi.org/10.1177/1098611109332422.

Rojek, Jeff, Richard Rosenfeld, and Scott Decker. 2012. "Policing Race: The Racial Stratification of Searches in Police Traffic Stops." Criminology 50 (4): 993-1024. https://doi.org/10.1111/j.1745-9125.2012.00285.x.

Rothstein, Richard. 2017. The Color of Law: A Forgotten History of How Our Government Segregated America. New York; London: Liveright Publishing Corporation.

Rowangould, Gregory M. 2013. "A Census of the US Near-Roadway Population: Public Health and Environmental Justice Considerations." Transportation Research Part D: Transport and Environment 25 (December): 59-67. https://doi.org/10.1016/j.trd.2013.08.003.

Royce, Edward Cary. 1993. The Origins of Southern Sharecropping. Labor and Social Change. Philadelphia: Temple University Press.

Sallis, James F., Robert B. Cervero, William Ascher, Karla A. Henderson, M. Katherine Kraft, and Jacqueline Kerr. 2006. "An Ecological Approach to Creating Active Living Communities." Annual Review of Public Health 27: 297-322. https://doi.org/10.1146/annurev.publhealth.27.021405.102100.

Sanchez, Thomas W., and James F. Wolf. 2007. "Environmental Justice and Transportation Equity: A Review of MPOs." In Growing Smarter: Achieving Livable Communities, Environmental Justice, and Regional Equity, edited by Robert D. Bullard, 249-71. Cambridge, MA and London, UK: MIT Press.

Schlosberg, David. 2009. Defining environmental justice: theories, movements, and nature. 1. publ. in paperback. Oxford: Oxford Univ. Press.

Schneider, Robert J. 2013. "Theory of Routine Mode Choice Decisions: An Operational Framework to Increase Sustainable Transportation." Transport Policy 25: 128-37. https://doi.org/10.1016/j.tranpol.2012.10.007.

Schneider, Robert J., Jennifer Kusch, Anne Dressel, and Rebecca Bernstein. 2018. "Can a TwelveWeek Intervention Reduce Barriers to Bicycling Among Overweight Adults in Low-Income Latino and Black Communities?" Transportation Research Part F: Traffic Psychology and Behaviour 56 (July): 99-112. https://doi.org/10.1016/j.trf.2018.03.023. 
Schneider, Robert J., Rebecca Sanders, Frank Proulx, and Hamideh Moayyed. 2021. "United States Fatal Pedestrian Crash Hot Spot Locations and Characteristics." Journal of Transport and Land Use 14 (1): 1-23. https://doi.org/10.5198/jtlu.2021.1825.

Schweitzer, Lisa. 2014. "Planning and Social Media: A Case Study of Public Transit and Stigma on Twitter." Journal of the American Planning Association 80 (3): 218-38. https://doi.org/10.1080/01944363.2014.980439.

Sciara, Gian-Claudia, and Martin Wachs. 2007. "Metropolitan Transportation Funding: Prospects, Progress, and Practical Considerations." Public Works Management \& Policy 12 (1): 378-94. https://doi.org/10.1177/1087724X07303987.

Seiler, Cotten. 2006. “'So That We as a Race Might Have Something Authentic to Travel By': African American Automobility and Cold-War Liberalism.” American Quarterly 58 (4): 10911117. https://doi.org/10.1353/aq.2007.0015.

Seo, Sarah A. 2019. Policing the Open Road: How Cars Transformed American Freedom. Cambridge, Massachusetts: Harvard University Press.

Shahum, Leah. 2020. “Acting for Racial Justice \& Just Mobility.” Vision Zero Network. June 8, 2020. https://visionzeronetwork.org/acting-for-racial-justice-just-mobility/.

Sharp, Elaine B. 2014. "Politics, Economics, and Urban Policing: The Postindustrial City Thesis and Rival Explanations of Heightened Order Maintenance Policing." Urban Affairs Review 50 (3): 340-65. https://doi.org/10.1177/1078087413490397.

Sheller, Mimi. 2015. "Racialized Mobility Transitions in Philadelphia: Connecting Urban Sustainability and Transport Justice." City \& Society 27 (1): 70-91. https://oi.org/10.1111/ciso.12049.

Brooklyn, NY: Verso.

Sheller, Mimi, and John Urry. 2000. "The City and the Car." International Journal of Urban and Regional Research 24 (4): 737-57. https://doi.org/10.1111/1468-2427.00276.

Shoub, Kelsey, Derek A. Epp, Frank R. Baumgartner, Leah Christiani, and Kevin Roach. 2020. "Race, Place, and Context: The Persistence of Race Effects in Traffic Stop Outcomes in the Face of Situational, Demographic, and Political Controls." Journal of Race, Ethnicity and Politics 5 (3): 481-508. https://doi.org/10.1017/rep.2020.8.

Smith, Melody, Jamie Hosking, Alistair Woodward, Karen Witten, Alexandra MacMillan, Adrian Field, Peter Baas, and Hamish Mackie. 2017. "Systematic Literature Review of Built Environment Effects on Physical Activity and Active Transport - an Update and New Findings on Health 
Equity." International Journal of Behavioral Nutrition and Physical Activity 14 (1): 158. https://doi.org/10.1186/s12966-017-0613-9.

Sorin, Gretchen. 2021. Driving while Black: African American travel and the road to civil rights. New York: Liverlight.

Steg, Linda, Charles Vlek, and Goos Slotegraaf. 2001. "Instrumental-Reasoned and SymbolicAffective Motives for Using a Motor Car." Transportation Research Part F: Traffic Psychology and Behaviour 4 (3): 151-69. https://doi.org/10.1016/S1369-8478(01)00020-1.

Stuesse, Angela, and Mathew Coleman. 2014. "Automobility, Immobility, Altermobility: Surviving and Resisting the Intensification of Immigrant Policing." City \& Society 26 (1): 51-72. https://doi.org/10.1111/ciso.12034.

Toomey, Russell B., Adriana J. Umaña-Taylor, David R. Williams, Elizabeth Harvey-Mendoza, Laudan B. Jahromi, and Kimberly A. Updegraff. 2014. “Impact of Arizona's SB 1070 Immigration Law on Utilization of Health Care and Public Assistance Among Mexican-Origin Adolescent Mothers and Their Mother Figures." American Journal of Public Health 104 (S1): S28-34. https://doi.org/10.2105/AJPH.2013.301655.

Transportation Alternatives. 2020. "The Case for Self-Enforcing Streets." New York. https://static1.squarespace.com/static/5cab9d9b65a707a9b36f4b6c/t/5eec1235fe73d720da41258 9/1592529462229/CaseForSelfEnforcingStreets.pdf.

U. S. Census Bureau. 2020. "American Community Survey 5-Year Estimates: 2014--2018." https://www.census.gov/programs-surveys/acs.

Untokening Collective. 2017. "Untokening 1.0 - Principles of Mobility Justice." http://www.untokening.org/updates/2017/11/11/untokening-10-principles-of-mobility-justice.

Vigar, Geoff. 2017. "The Four Knowledges of Transport Planning: Enacting a More Communicative, Trans-Disciplinary Policy and Decision-Making." Transport Policy 58 (August): 39-45. https://doi.org/10.1016/j.tranpol.2017.04.013.

Warren, Patricia, Donald Tomaskovic-Devey, William Smith, Matthew Zingraff, and Marcinda Mason. 2006. "Driving While Black: Bias Processes and Racial Disparity in Police Stops." Criminology 44 (3): 709-38. https://doi.org/10.1111/j.1745-9125.2006.00061.x.

Webb Jamme, Huê-Tâm, Deepak Bahl, and Tridib Banerjee. 2018. "Between 'Broken Windows' and the 'Eyes on the Street:' Walking to School in Inner City San Diego." Journal of Environmental Psychology 55 (February): 121-38. https://doi.org/10.1016/j.jenvp.2018.01.004.

Weitz, Rose. 2008. "Who's Afraid of the Big Bad Bus? NIMBYism and Popular Images of Public Transit." Journal of Urbanism: International Research on Placemaking and Urban Sustainability 1 (2): 157-72. https://doi.org/10.1080/17549170802221500. 
Williams, Sarah. 2020. Data Action: Using Data for Public Good. The MIT Press. https://oi.org/10.7551/mitpress/12261.001.0001.

Wilson, James Q., and George L. Kelling. 1982. "Broken Windows: The Police and Neighborhood Safety.” The Atlantic, March 1982. https://www.theatlantic.com/magazine/archive/1982/03/broken-windows/304465/.

Wilson, Kea. 2021. "Virginia Policy Could End Jaywalking Stops." Streetsblog USA (blog). January 4, 2021. https://usa.streetsblog.org/2021/01/04/virginia-policy-could-end-jaywalkingstops/.

Wisniewski, Mary. 2018. "Black Neighborhoods Still See Most Bike Tickets, Police Data Show." Chicago Tribune, February 12, 2018, sec. Column. http://www.chicagotribune.com/news/columnists/wisniewski/ct-met-bike-tickets-getting-around20180211-story.html.

Woodward, C. Vann. 1964. "Plessy v. Ferguson: The Birth of Jim Crow." American Heritage, April 1964. https://www.americanheritage.com/plessy-v-ferguson.

Yu, Chia-Yuan. 2014. "Environmental Supports for Walking/Biking and Traffic Safety: Income and Ethnicity Disparities." Preventive Medicine 67 (October): 12-16. https://doi.org/10.1016/j.ypmed.2014.06.028.

Zuk, Miriam, Ariel H. Bierbaum, Karen Chapple, Karolina Gorska, and Anastasia LoukaitouSideris. 2018. "Gentrification, Displacement, and the Role of Public Investment." Journal of Planning Literature 33 (1): 31-44. https://doi.org/10.1177/0885412217716439. 